\title{
Fixed point theorems for almost contractions in generalized metric spaces
}

\author{
LULJETA KIKINA, KRISTAQ KIKINA and ILIR VARDHAMi
}

\section{ABSTRACT.}

Fixed point theorems for almost contractions in generalized metric spaces are proved. The obtained results are extensions and generalizations, from metric space setting to generalized metric space setting, of many well-known fixed point theorems in literature.

\section{REFERENCES}

[1] Abbas, M. and Ilic, D., Common fixed points of generalized almost nonexpansive mappings, Filomat, 24 (2010), No. 3, 11-18

[2] Abbas, M., Vetro, P. and Khan, S. H., On fixed points of Berinde's contractive mappings in cone metric spaces, Carpathian J. Math., 26 (2010), No. 2, $121-133$

[3] Azam, A. and Arshad, M., Kannan fixed point theorem on generalized metric spaces, J. Nonlinear Sci. Appl., 1 (2008), No. 1, 45-48

[4] Babu, G. V. R., Sandhya, M. L. and Kameswari, M. V. R., A note on a fixed point theorem of Berinde on weak contractions, Carpathian J. Math., 24 (2008), No. 1, 8-12

[5] Berinde, V., Approximating fixed point of weak contractions using the Picard iteration, Nonlinear Analysis Forum, 9 (2004), No. 1, 43-53

[6] Berinde, V., Iterative Approximation of Fixed Points, Springer, Berlin Heidelberg New York, 2007

[7] Berinde, V. and Berinde, M., On a general class of multi-valued weakly Picard mappings, J. Math. Anal. Appl., 326 (2007), $772-782$

[8] Berinde, V. and Pacurar, M., Fixed points and continuity of almost contractions, Fixed Point Theory, 9 (2008), No. 1, 23-34

[9] Bianchini, R. M. T., Su un problema di S. Reich riguardante la teoria dei punti fissi, Boll. Un. Mat. Ital., 5 (1972), 103-108

[10] Branciari, A., A fixed point theorem of Banach-Caccippoli type on a class of generalized metric spaces, Publ. Math. Debrecen, 57 (2000), 31-37

[11] Das, P., A fixed point theorem on a class of Generalized metric spaces, Korean J. Math. Sciences, 1 (2002), 29-33

[12] Das, P. and Dey, L. K., A fixed point theorem in a Generalized metric space, Soochow Journal of Mathematics, 33 (2007), 33-39

[13] Das, P. and Dey, L. K., Porosity of certain classes of operators in generalized metric spaces, Demonstratio Math., 42 (2009), No. 1, 163-174

[14] Das, P. and Dey, L. K., Fixed point of contractive mappings in a generalized metric space, Math. Slovaca, 59 (2009), No. 4, 499-504

[15] Kamran, T., Multivalued f-weakly Picard mappings, Nonlinear Analysis, 67 (2007), No. 7, 2289-2296

[16] Kannan, R., Some results on fixed points II, Amer. Math. Monthly, 76 (1969), 405-408

[17] Kikina. L. and Kikina, K., A fixed point theorem in generalized metric spaces, Demonstratio Math., 46 (2013), No. 1, 181-190

[18] Kikina, L. and Kikina, K., On fixed point of a Ljubomir Ciric quasi-contraction mapping in generalized metric spaces, Pub. Math. Debrecen, In print. Ref. No.: 5528 (2013), 1-6

[19] Kikina, L. and Kikina, K., Fixed points on two Generalized Metric Spaces, Int. J. Math. Anal., 5 (2011), No. 30, 1459-1467

[20] Olatinwo, M. O., Some fixed point theorems for weak contraction conditions of integral type, Acta Univ. Apulensis Math. Inform., 24 (2010), 331-338

[21] Rhoades, B. E., A comparison of various definitions of contractive mappings, Trans. Amer. Math. Soc., 226 (1977), 256-290

[22] Reich, S., Some remarks concerning contraction mappings, Canad. Math. Bull., 14 (1971), 121-124

[23] Samet, B., Discussion on A fixed point theorem of Banach-Caccioppoli type on a class of generalized metric spaces by A. Branciari, Publ. Math. Debrecen, 76 (2010), No. 3-4, 493-494

[24] Sarma, I. R., Rao, J. M. and Rao, S. S., Contractions over generalized metric spaces, J. Nonlinear Sci. Appl., 2 (2009), No. 3, 108-182

[25] Suzuki, T., Fixed point theorems for Berinde mappings, Bull. Kyushu Inst. Tech. Pure Appl. Math., 58 (2011), 13-19

DePARTMENT OF MATHEMATICS AND COMPUTER SCIENCE

UNIVERSITY OF GJIROKASTRA, ALBANIA

E-mail address: gjonileta@yahoo.com

E-mail address: kristaqkikina@yahoo.com

DEPARTMENT OF MATHEMATICS

University OF TIRANA, Albania

E-mail address: ivardhami@yahoo.com 